\title{
NEGROPHOBIA AND ANTI-NEGRITUDE IN MORRISON'S THE BLUEST EYE
}

\author{
Nasser Maleki, \\ Razi University, Iran. \\ Mohammad Javad Haj'jari, \\ Razi University, Iran.
}

\begin{abstract}
Morrison's The Bluest Eye (1970) stands as an outstanding novel of character regarding the destroying effects of Negrophobia among the black on themselves. Pecola Breedlove's agony over blue eyes arises from an undeveloped Negritude, the discord within the black society towards Negrophobia, and a strong fear of her own race. Pecola's non-reconciliation with her black identity, inflamed by domestic violence and the black societal indifference, craves for blue eyes, the paradigm of whiteness and white beauty. Consequently, she develops an anti-black neurosis because of a feeling of nonexistence both within her community and the white society, although she remains entangled within the interstitial space of blackness and whiteness as in a purgatory of suffering. Her final madness is the culmination of a black human being who is able neither to accept and defend her Negritude, nor to transcend to a seemingly higher, but fake, state of being.
\end{abstract}

Keywords: Identity; Negrophobia; Negritude; Pecola and The Bluest Eye 
Identity crisis among black folk has always been an important issue because of their exploitation and abuse by the white people. The black human being has always had to fight the degradation by the white dominancy and the inferiority complex developed out of that. Existing in such a void has never been easy for a black man or woman. Problems are doubled when black women are the main concern, since they are both under the subjugation of their black men and that of the white people. As Fanon says, "We must see whether it is possible for the black [...] to overcome [... their] feeling of insignificance, to rid [their] life of the compulsive quality that makes it so like the behavior of the phobic" (2008: 35). Thus the black suffer "from an inadequacy in all human communication" which entangle them in "an unbearable insularity" (35). Since there is no pleasure in such insularity, the only way out is the way which "leads into the white world" (36).

There is also the danger of domestic problems which include both physical and mental neuroses. According to Fanon, "a normal Negro child, having grown up within a normal family, will become abnormal on the slightest contact with the white world" (111). And the problem worsens if the child is even mistreated in his/her native family as well. Mental "sickness" thus arises from "the family environment" (110). Thus Negritude remains undeveloped or develops in fragments, and Negrophobia emerges both from the contact with the white and as an escape from blackness. As Fanon remarks,

When the Negro makes contact with the white world, a certain sensitizing action takes place. If his psychic structure is weak, one observes a collapse of the ego. The black man stops behaving as an actional person. The goal of his behavior will be The Other (in the guise of the white man), for The Other alone can give him worth. That is on the ethical level: self-esteem. (119)

The black sense of "inferiority" is thus "conscious" (116), and subjection to black indifference and white dominancy causes the black figure to live in "an ambiguity that is extraordinarily neurotic" (148).

Pecola Breedlove's lack of love in the black community, as her mother craves for the white life, creates a breach in the mother-daughter relationship which is exacerbated by incest. This lack of love is doubled by being a black girl too, which is itself tripled by the sense of ugliness as well. She wants to be loved but she is ugly, humiliated, marginalized, and alienated. She lacks parental love; she is poor; she is raped; she is black. She thus develops an inferiority complex. And what is the best model for development? She takes it as the blue eye, the paradigm of white beauty. Thus, she develops delusions; she faces problems in the development of her 'bodily schema. Embroidering on this issue Fanon believes that "consciousness of the body is 
solely a negating activity. It is a third-person consciousness. The body is surrounded by an atmosphere of certain uncertainty" (2008: 83). Her being becomes a prison, the key to which are blue eyes as windows to the blue sky. Such physical operation acts as "a serum for denegrification" to become white (Fanon, 2008: 83). This may make it likely for the miserable Pecola to whiten herself, and thus, as Fanon analyzes such behaviors, "to throw off the burden of that corporeal malediction" (84).

Since the black are "ugly" in the white's eyes (86), they are "the slave[s] not of the "idea" that others have" of them but of their own "appearance". They are already "being dissected under white eyes, the only real eyes" (87). This moment of identification is the same as the Lacanian mirror stage in which, in a kind of black discourse, the black man/woman comes to realize him/herself in the mirror of or the reflection from the white eye in which he/she sees an ugly image. Growth out of that ugly framework to a form in accordance with white beauty is thus the black's identity crisis. Regarding the "living reactions of the woman of color to the European" concept of beauty, there are two types of women: "the Negress and the mulatto". The first has merely one concern: "to turn white", while the second desires "not only to turn white but also to avoid slipping back" (Fanon, 2008: 38). Pecoula's ugliness makes her crave for beauty. It is because the "Negress feels inferior that she aspires to win admittance into the white world." In this attempt she is after what is titled as "affective erethism" (42). "Erethism" is "an unusually high sensitivity to sensory stimulation" (Reber, 1995: 258), which is developed in Pecola when she sees "blue eyes". "Blue eyes [...] frighten the Negro [and the Negress]" (Fanon, 2008: 29). Pecola puts herself into "a complete situational neurosis" (43), to run away from her ugliness and "feeling of nonexistence" (106).

Considering these issues, this article tries to explain Pecola's development of madness out of such state of living, a living between Negritude and self-imposed Negrophobia.

The Bluest Eye is Toni Morison's first novel. The plot of the story is about a little black girl, Pecola, who is taken as a boarder by the MacTrees. Pecola wants to have blue eyes. She believes that if she gains blue eyes, her ugliness would disappear and she would gain love, attraction, and consequently security. We think that Morrison has used the singular 'eye' not as an organ, but metaphorically as something designating 'the look' of the whites who consider blacks as inferior people. Such feelings exist because of differences between white and black societies. The difference finally leads to a search for identity. Deleuze claims that all identities are effects of difference; identities are neither logically nor metaphysically prior to difference. He argues that "there exist differences of nature between things of the same genus" (1991: 33). That is, not only are no two things ever the same, the 
categories we use to identify individuals in the first place derive from differences.

With the passage of time, Pecola joins the stormy life of her family; she becomes the mate of miseries, insults, and frustrations imposed on her by her parents and her brother. Moreover, Pecola's cataclysmic desire for blue eyes brings about her identity crises. Meanwhile, she continually receives confirmation of her own sense of ugliness-the grocer looks right through her when she buys candy; boys make fun of her; and a light-skinned girl, Maureen who temporarily befriends her, makes fun of her too. She is wrongly blamed for killing a boy's cat and is called a "nasty little black bitch" by his mother (Morrison, 2004: 86).

In the course of the novel, we discover that Pecola's parents have both had difficult lives. Pecola's mother, Pauline, is an isolated melancholic handicapped. Her whole life has been a fantasy full of things which white people have and she does not. She feels most alive when she is at work, cleaning a white woman's house, and it is there where she finds a sense of life. Her longing for the white woman's house is another sign of domination on the part of white people. Cholly, Pecola's father, was abandoned by his parents and raised by his great aunt who died when he was a lad. He ran away to find his father but was rebuffed by him. By the time he met Pauline, he was a wild and rootless man. He feels trapped in his marriage and has lost interest in life. Cholly returns home one day and finds Pecola washing dishes. With mixed motives of tenderness and hatred that are fueled by guilt, he rapes her. This scene is the crucial revelation of male domination in the novel. When Pecola's mother finds her unconscious on the floor, she disbelieves Pecola's story and beats her. Pecola goes to Soaphead's Church, a shameful mystic, and asks him for blue eyes. Instead of helping her, he has her kill a dog he dislikes. Paradoxically, the Negro/Negress then becomes "a toy in the white man's hands" (Fanon, 2008: 108).

The MacTrees find out that Pecola has been impregnated by her father, and unlike the rest of the neighborhood, they want the baby to live. They spend the money they have been saving for a bicycle and plant marigold seeds. They believe that if the flowers live, so will Pecola's baby. The flowers refuse to bloom, and Pecola's baby dies when it is born prematurely. Cholly, who rapes Pecola a second time and then runs away, dies in a workhouse. Pecola goes mad, believing that her cherished wish has been fulfilled and that she has the bluest eyes in the world. Consequently, Pecola moves through traumatic experiences, including marginalization and the search for home and wholeness. And her trauma is aggravated because she is a girl dwelling in a phallocentric culture.

Right from the beginning of the novel, the reader is privy to Pecola's fate from the 
italicized narrative of Dick and Jane's primer story. It serves as an ironic contrast to the limited and the drab world of black characters, particularly MacTeers. Pecola is introduced to the readers as the anonymous "she" who shares Claudia and Frieda's bed. Mrs. MacTeer refers to Pecola "as a 'case" (Morrison, 2004: 18), after her father has burned up his house and put his wife and children outdoors. She arrives at MacTeers' house without anything, "no little paper bag with other dress, or a nightgown, or two pair of whitish cotton bloomers" (20). One is moved to sympathy with her condition caused by poverty, race hatred, ugliness, and victimization.

Black people are indoctrinated that their culture is inferior to the white. Such indoctrination has created the duality of black consciousness. Dubey in his book, The Soul of Black Folk, calls this duality of consciousness "double consciousness". He believes that "it is a peculiar sensation, double consciousness, this sense of always looking at one's self through the eyes of others, of measuring one's soul by the tape of a world that looks on in amused contempt and pity" (1975: 14). The victim of this cultural disease dwells in two opposing worlds and experiences a psychological conflict. Pecola is an example of this phenomenon. She is convinced that the Breedloves are damaged, spoiled, and blemished people and are thus undervalued by others. Therefore, it is difficult to have equal access to the functioning systems in the society. In fact, the white race dictates its culture on the black to sway their minds. Claudia, the narrator of the novel, realizes this situation: "It was as though some mysterious all-knowing master had given each one a cloak of ugliness to wear, and they had each accepted it without question. The master had said, "You are ugly people." They have looked about themselves and saw nothing to contradict the statement" (Morrison, 2004: 39). Here the master epitomizes the white domination which imbues black people with the feelings of ugliness and inferiority. It is this sense of ugliness, inherited from her mother, that causes Pecola to suffer. For Pecola and her family, ugliness is a matter of personal conviction introduced by their white masters and willingly adopted by them. Pecola's ugliness, like a mantle, covers her body and self. Her mind is perplexed and is unable to help her value herself. "She hid behind hers. Concealed, veiled, eclipsed -- peeping out from behind the shroud very seldom, and then only to yearn for the return of her mask" (Ibid.: 39). The feeling of ugliness can be interpreted in Foucault's term as discourse; it is the hidden workings of operations obscured by the superficial objectivity of its constituent words and sentences. Her cataclysmic desire for blue eyes is an indication of her identity crisis, referred to by Deleuz as well, from which Pecola suffers. Her absolute blackness confirms other delimiting characteristics of her precarious position at the bottom of the social scale. Pecola is actually a victim of a white society which treats people according to their skin color, a society which conditions her to believe and internalize that she is ugly because she does not epitomize Western values, standards, and conceptions of beau- 
ty. Barbara Christian observes that "Pecola's destiny is ultimately determined by the myth of beauty and goodness one culture has foisted on another" (1989: 153). Pecola's gullibility dupes her into believing that the white myth of beauty is an appropriate avenue for self-definition and self-affirmation. In fact, she is despised, detested, and ostracized by her teachers, classmates, and people around her. That is why she devalues her healthy self by adopting the white standards of beauty to acquire "the bluest eye", the ultimate standard of beauty. "White American prescription for beauty includes blonde hair, white skin, and above all, blue eyes" (Otten, 1993: 17-18). She raises her spirit by subscribing to the white cultural definition of beauty and worthiness which precipitates her into losing herself for a place in the racist world. She rejects her true self to obtain a wrong one. As Melissa Walker points out, the novel is

a timeless study of a social outcast (Pecola) who rejects her-
self and one-time outsider (Claudia) who climbs into the
mainstream of society and in the process renounces those left
behind. It is also a timely novel in its treatment of the tragic
consequences for those who attempt to escape blackness by an
unrealistic and self-destructive yearning for (blue eyes) and
privileges of whiteness or by renouncing their historical iden-
tity in order to accommodate to the white world. (1991: 50)

This kind of duality is the reason for her suffering. As an adult, Pecola longs for love but her ugly image in the mirror prevents her from entertaining such an idea. "Long hours she sat looking in the mirror, trying to discover the secret of her ugliness that made her ignored or despised at school, by teachers and classmates alike. She was the only member of her class who sat alone at a double desk" (Morrison, 2004: 44).

Pecola thinks that love and acceptance come through blue eyes. For her, acquiring blue eyes is the only way to get out of her impasse, to negate her position as a pariah, and to transcend her sense of nothingness in the social atmosphere of Lorain. "It had occurred to Pecola some time ago that if her eyes [...] were different, that is to say, beautiful, she herself would be different [...] If she looked different, beautiful, maybe Cholly would be different. Maybe they'd say, 'Why look at pretty-eyed Pecola. We mustn't do bad things in front of those pretty eyes"' (Ibid.: 45). Her recoil to the world of fantasy gives her a feigned and spurious feeling of beauty. It seems that the bluest eye Pecola dreams about is a metonymy for the white hegemonic culture that has too often set the standards of beauty and individual worth. Pecola's craving for blue eyes is tantamount to her desire for the specific beauty which the white culture designates as a virtue. She sees them in the face of a black cat and in the adored faces of white children, particularly Shirley Temple and Mary Janes. She is hypnotized by the picture of Shirley Temple embossed on the mug. She enjoys gazing at its blue eyes. She likes such kinds of characteristics and associates having blue eyes with 
beauty and loveliness. Pecola goes further and wishes to vanish and to be re-created as a white human being, as for her the outward appearance is associated with virtue. This distorted view augments her suffering, and her troubles begin to grow from here.

However, her mania for the white idols of beauty makes her pay a very high price, since she is plunged into madness. This idea is incongruous in itself, as it does not have a magic power or a cosmetic operation to transform Pocola's complexion at the time of the setting of the novel. Nevertheless, she starts praying ardently every night for blue eyes so that she may be accepted in the white society: "Throwing in this way, into the binding conviction that only a miracle could relieve her, she would never know her beauty. She would see only what there was to see: the eyes of other people" (Morrison, 2004: 45). This shows that Pecola dwells in an illusory world where she enjoys a state of euphoria over blue eyes. She is maniacally preoccupied with beauty and love.

Morrison strongly believes that the western concept of beauty has no relevance to black women. In "Behind the Making of the Black Book", she asserts that

the concept of physical beauty as a virtue is one of the dumbest, most pernicious and destructive ideas of the western world and we should have nothing to do with it. Physical beauty has nothing to do with our past, present, or future. Its absence or presence was only important to 'them', the white people who used it for anything they wanted. (1974: 89).

Morrison here reveals her indictment of the standards of the white culture. In the novel she asserts that "Romantic love" and "the idea of physical beauty" are "probably the most destructive ideas in the history of human thought" (Morrison, 2004: 111). She denounces those blacks who are influenced by the incongruous white culture. In western discourse, outward beauty is associated with inner virtue and goodness. In her innocence, Pecola decides to transgress the racial code by struggling to have a magical operation to have blue eyes. She erroneously thinks that if she gets blue eyes, the white world will accept her, her teachers and classmates will respect her and smile at her the same way they smile at Maureen Peal, and her parents may stop fighting. It reminds us of the concept of Bakhtin's carnivalism. Bakthin takes carnivalism "as a second culture" as opposed to "the official culture" which was developed by common people during the medieval era and into the "early, modern period". That carnivalism brings about "indeterminacy" and "a certain semantic open-endedness" for the official structures. This could provide a way of talking about "how subjects might respond to dominant discourses through the modalities of counter-identification or even misidentification" (Bristol, 1985: 36). Yet she finally ends up in madness because her eyes have not changed in reality. 
The only thing changed is her way of seeing; she cannot overcome her ugliness and blackness. Pecola remains Pecola. The society still looks down upon her and considers her a nasty girl. Nature reflects Pecola's suffering too. The seeds of Marigolds that Claudia and Frieda sow do not sprout, perhaps as a demonstration against racial inequality that causes the degradation. Interestingly, the marigolds rebel against targeting Pecola, while black and white people remain silent. For Claudia, Pecola's pregnancy assumes a cosmic proportion which affects the growth of marigolds everywhere. Such reflections of the stunted growth of Pecola echoe Morrison's strong protest against the vituperative racism that dismantles black identity.

Pecola experiences pain, torment, rejection, and brutalization. Devoid of her parents' love, she cannot enjoy life at home, since her parents are constantly in an unremitting brutal battle. She is left adrift in life without any comforts or guidance afforded to other children, even those who are poor like her. Thus, she innocently posits a question, which always nags her: "How do you do that? I mean, how do you get somebody to love you?" (Morrison, 2004: 33). But no one answers her question because Frieda is asleep and Claudia does not know that. They do not care about their children or give them a sense of worth, since they have none of that worth. Pecola is the scapegoat of her family and community. Her real suffering begins when she sees the mundane light and cries. She is born to a woman who is torn by poverty, racism, and sexism, and therefore, she is unable to rear her daughter or at least to find an outlet for her dilemma. Instead, she teaches her how to endure abuse and humiliation. Pauline's way of nurturing her daughter implants self-loathing in Pecola's psyche and precipitates her into dementia. In addition to what she had suffered at the hands of Breedloves, she experiences many sufferings which lead her almost to obliterate her identity. Morrison emphasizes the damaging effects of assimilating white values and culture into black people for whom Pecola is a representative. The most chilling incident is Cholly's incestuous act. Pecola is raped and impregnated by her father in a brutal way which hurts her dignity and decency and denudes Cholly of his fatherly instinct. Her only shelter, her father, destroys her being. This unnatural act stems from oppressive and hostile environments from which Cholly suffers. When Cholly staggers home, drunk, and sees his daughter washing the dishes, he feels pity for her degraded and hapless condition. Since he is helpless to do anything to assuage Pecola's broken, "crouching" spirit (Ibid.: 146), he is either unconsciously driven by an irresistible rage caused by a drunken stupor and thus rapes her or consciously commits the incestuous act to express his love and tenderness. "The attitude of the black man toward the white, or toward his own race, often duplicates almost completely a constellation of delirium, frequently bordering on the region of the pathological" (Fanon 2008: 43). Pecola's father develops such delirium, culminated in the rape scene while he is drunk. 
Another terrifying incident is the inhuman treatment Pecola receives from the old white shopkeeper, Mr. Yacobowsky, when she enters his candy store to buy Mary Jane some candy. On the way to the shop, Pecola sees some dandelions with which she associates herself. In fact, it is the most painful experience of the "look" that Pecola has ever experienced. The shopkeeper frowns at her, paying no attention to her as if she does not exist. "Somewhere between retina, between vision and view, his eyes drawback, hesitate and hover. At some fixed point of time and space, he senses that he need not waste the effort of a glance. He does not see her because there is nothing to see" (Morrison, 2004: 47). He stares at her in a way that denies human recognition. He does not want to waste his time looking at an unwanted thing. Here Pecola is not identified as the Other but rather as a non-existent human being. He reduces her to a point of invisibility. Pecola attempts to win his attention; she "looks up at him and sees the vacuum where curiosity ought to lodge." But there is nothing but "the total absence of human recognition -- the glazed separateness" (47). Even when he wants to take the pennies, he takes them from Pecola gingerly not to touch her black skin: "[S] he holds the money toward him. He hesitates, not wanting to touch her hand" (48). When he recoils at the touch of her hand, she accepts his affront with shame. She becomes angry which "is better. There is a sense of being in anger. A reality and presence. An awareness of worth." But her anger "will not hold" and her thirst is "too quickly quenched". And "shame wells up again" (49). Since Pecola accepts self-condemnation and self-rejection, her anger is vanquished. She is much injured by this incident that she cannot resist the shopkeeper's dehumanizing stance. The fact is that she is not emboldened by inner strength and confidence. She believes that "the distaste must be for her, for blackness ... that creates the vacuum edged with distaste in white eyes" (47). While Pecola is going to Yacobowsky's shop, she shows overwhelming interest in the world around her and considers the dandelion beautiful. But after being insulted by the shopkeeper, she has no interest in the world around her. Now she thinks that dandelions "are ugly" and "weeds" (48). As she changes her judgment about dandelions, she internalizes the belief that she is unworthy of notice. The "look" of others, particularly of whites and half-whites, confuses her and infuses a fear in her psyche. Her traumatic experiences of the denial of self by whites negate her very existence. The scene is also reveals that Pecola's dilemma is "the Look", the hegemonic gaze that renders her ugly and vulnerable.

Pecola is a victim of the "look". She sees herself as ugly through the eyes of others. She conjures up a negative image of herself instigated by the venerated, hegemonic, and monolithic culture. This negative image pushes her to the rim of society and forces her to occupy a peripheral space. Her feeling of ugliness ensues from the hegemonic culture that brainwashes the minds of blacks in such a way that they 
develop self-hatred. Whites imbue in the black psyche the feeling of ugliness and inferiority. The internalization of the white cultural etiquette degrades the life of the Breedloves. Ugliness and inferiority are reified in Pecola's consciousness. Accordingly, she becomes more determined to acquire blue eyes. Although cherished blue eyes are appealing to Pecola, they will have detrimental effects on her psyche. She withdraws into an imaginative world of her own. In this way, Pecola rejects her negritude and develops negrophobia; the deification of her oppressor's culture leads to a negation of her own culture. She loses an integrated sense of herself.

Pecola does not only suffer at the hands of whites but also at the hands of her own people. Intra-racism is an ingredient of the black spectrum; at school, her teachers and friends taunt her for her dark skin; people point fingers at her to indicate her inferiority; she is the pariah of her society. Instead of developing a love of their own race, blacks develop self-hatred. One can argue here that blacks' self-hatred and contempt of their own hue and pigmentation augment Pecola's estrangement from her family and community. It makes the situation more volatile and gives rise to her doleful situation.

Another incident that has debilitating effect on Pecola is the neighborhood's black boys who flock and dance around Pecola, ragging her for having a swarthy skin and the sleeping habits of her father. They chant "Yadaddsleepsnakked" and chide Pecola for not being "civilized" according to the western standards, since she sees her father naked as he passes her bedroom, an allusion to Ham's seeing Noah naked and thus cursed as the ancestor of the black race (Genesis 9:20-27). They gaily revile and harass her by chanting an extemporized affront: "Black e mo. Black e mo. Ya daddy sleeps neked. Black e mo. Black e mo. Ya daddy sleeps neked” (Morrison, 2004: 62). Pecola is insulted and picked on by "matters over which [she] had no control: the color of her skin and speculations on the sleeping habits of an adult" (61). Her response to this heap of insults is indeed indicative of her vulnerability and helplessness. One is indeed moved by Morrison's vivid depiction of Pecola's reaction to the humiliation from the boys: "Pecola edged around the circle crying. She had dropped her notebook, and covered her eyes with her hands" (62). Moreover, it has a deep implication that young blacks do not extol their culture because they lack a sense of pride in their culture, in their negritude. They are gravely influenced by the white cultural invasion which has swayed their minds. Subscribing to the dominating culture, which considers those who do not cope with its etiquette and mores as uncivilized and crude, while refusing theirs, is the most dangerous factor that can annihilate black culture and identity. Morrison stresses the necessity for blacks to accept their blackness, abide by their culture, extol it, and attach to their cultural past in order to disinter their affluent culture and make it the anthem of black life in America. A typical example of immoral black-black treatment is the way Geraldine and Mau- 
reen treat Pecola. Geraldine admonishes her puckish and impish son, Junior, not to play with "niggers" because they are dirty people. Junior lures Pecola into his house, which greatly impresses Pecola. He throws the cat in her face and immediately locks them both in the room. To sooth her fright, she pets the cat which is black with blue eyes -- an image that magnifies her fantasy and desire to have blue eyes. But the cat jumps from the widow and dies. Instead of chastising her mischievous son, Geraldine castigates innocent Pecola. For Geraldine, Pecola is the embodiment of poverty, dirt, disorder, and ugliness which she has stridently managed to get rid of. In ordering Pecola to get out of her house, she is "attempting to rid herself of her fears of her own unworthiness, of her own shadow of blackness" (Awkward, 1993: 194). Maureen's innuendo wounds Pecola's psyche and alienates Maureen from her black race. Her duplicity, which manifests itself in her attempt to peroxide her hue and embrace the white culture, stems from belonging to a black culture. Pecola's response to this abuse echoes her response to Geraldine. "Pecola tucks her head in - a funny, sad, helpless movement. A kind of hunching of the shoulders, pulling in of the neck, as though she wanted to cover her ears" (Morrison, 2004: 69). The narrator registers Pecola's response in a way which arouses the reader's sympathy: "Pecola stood a little apart from us, her eyes hinged in the direction in which Maureen had fled. She seemed to fold into herself, like a pleated wing" (69). Even when Claudia and Frieda shout back at Maureen, Pecola does not realize that they are defending her. Instead, "she seemed to fold into herself, like a plated wing" (69). Claudia is instigated by this incident: "Her pain antagonized me" and "I wanted to open her up, crisp her edges, ram a stick down that hunches and curving spine, force her to stand and spit the misery out on the streets" (70-71). Through exposing the maltreatment that Pecola receives from the black boys, Maureen, and Geraldine, Morrison reveals the seepage of the white values into black culture and tacitly condemns it. "Ego-withdrawal as a successful defense mechanism is impossible" for the black people, since they require "a white approval" (Fanon, 2008: 36). Describing the phenomenon of ego-withdrawal, Anna Freud (1946) writes that

As a method of avoiding "pain," ego-restriction, like the various forms of denial, does not come under the heading of the psychology of neurosis but is a normal stage in the development of the ego. When the ego is young and plastic, its withdrawal from one field of activity is sometimes compensated for by excellence in another, upon which it concentrates. But, when it has become rigid or has already acquired an intolerance of "pain" and so is obsessionally fixated to a method of flight, such withdrawal is punished by impaired development. By abandoning one position after another it becomes one-sided, loses too many interests and can show but a meager achievement. (111) 
Not only Pecola achieves real blue eyes, she develops madness. Pecola could have resisted the radiance of the white eye to remain in a normal state of mind, since "it is a truism that "crossings between widely different races can lower the physical and mental level." Before having a comprehensive knowledge of the effects of "race-crossings", we should try our best to "avoid crossings between widely different races" (Mjoen, 1921: 60). But "not yet white, no longer wholly black" (Fanon, 2008: 106), Pecola is damned. "Identifying with the civilizing power" makes the black the victims of their own morality (150).

At the outset, Pecola aims to find love and affection among family and community. Since love does not have a place among the Breedloves, she does not experience it. She does not even identify it. Her father-mother love is characterized by agony and silence in their bed. It seems this deformed love is imparted to Pecola who wonders whether love is "choking sound and silence" (Morrison, 2004: 56). Love is an elusive obscurity for Pecola. The Breedloves storefront house is not congenial for fruitful love. Consequently, Pecola makes an effort to create her own world where she can acquire love, admiration, and acceptance among people. She thinks that blue eyes are an amulet and mascot of whiteness, beauty, love, pride, and security. Accordingly, she exerts her efforts only to acquire blue eyes. Her tale of suffering is really one of humiliation, marginalization, and alienation. She is isolated from people around her. Devoid of a constructive contact in the orbit of social situation, Pecola gets a chronic pain which she attempts to get rid of "by holding in her stomach" (Ibid.: 44). Deprived of an emotional bond through mother-daughter relationship and being engrossed in grinding poverty and torn by the onslaught of racism and sexism, raped by her father, battered by her mother, troubled by her ugliness, and silences by all, she is completely rejected and retreats into insanity. Her desire for blue eyes becomes more urgent after her rape and the demise of her child. Her interminable obsession with the blue eyes forces her into the hands of Soaphead. She asks him to fulfill her reverie and he promises her a miracle. Finally, she has the conviction that she has been given them. Her obsession with the spurious blue eyes is presented through hallucinations, her resistance to blinking, and her delusional view that others envy her gift. Her infatuation with her eyes is clearly seen in a tableau where she repeatedly looks at the mirror to reassure herself that her "blue eyes" are the bluest and the nicest. Although Pecola supplants the place of the looker or the gazer, she remains powerless and unable to attain love. Therefore, she totally withdraws into her world of fantasy and dementia. Morrison presents a picturesque description of Pecola in the novel:

The damage done was total. She spent her days, her tendril sapgreen days, walking up and down, up and down, and her head jerking to the beat of a drummer so distant only she could hear. Elbows bent, hands on shoulders, she flailed her arms like a bird in an 
eternal, grotesquely futile effort to fly. Beating the air, a winged but grounded bird, intent on the blue void it could not reach--could not even see--but which filled the valleys of the mind. (Ibid.:, 184)

She walks up and down as if she suffered from somnambulistic interminable walking. These useless and repetitive movements suggest the disintegration of her psyche. As an ingénue, she believes that she has been granted blue eyes and lives with that delusion. Yet these eyes symbolize the trauma of not being loved. As such, her negrophobia not only serves the white race, but also challenges the black's attempt at survival and their resistance for negritude. The delusional state of Pecola hints to the fact that the interstitial state of identity in a white society poses its ideals in a way that the black race at times is disillusioned into dismantling itself, while negritude can be one of the best solutions against such suffering.

\section{References}

Awkward, Michael. 1993. “The Evil of Fulfillment': Scapegoating and Narration in The Bluest Eye." Toni Morrison: Critical Perspectives Past and Present. Ed. Henry Louis Gates, Jr. and K. A. Appiah. New York, Amistad, 175-209.

Bristol, Michael. 1985. Carnival and Theater: Plebeian Culture and the Structure of Authority in Renaissance England. London, Methuen.

Christian, Barbara. 1989. Black Feminist Criticism: Perspectives on Black Women Writers. New York, Pergamon Press.

Deleuze, Gilles. 1991. Trans. Empiricism and Subjectivity. Montreal, McGillQueen's University Press.

Dubey, Madhu. 1975. Black Women Novelists and the Nationalist Aesthetic. Bloomington and Indianapolis, Indiana University Press.

Fanon, Franz. 2008. Black Skin, White Mask. London, Pluto Press.

Freud, Anna. 1946. The Ego and the Mechanism of Defense. New York, International Universities Press.

Morrison, Toni. 1974. "Behind the Making of the Black Book". Black World 23, 86-90

Morrison, Toni. 2004. The Bluest Eye. New York, Rosetta Books, LLC. Mjoen, Jon Alfred. 1921. "Harmonic and Disharmonic Race-crossings." Eugenics in Race and State, Vol. II, 60.

Otten, Terry. 1991. "Horrific Lover in Toni Morrison's Fiction.” Modern Fiction Studies 39, 3-4 (Fall/ Winter), 651-67.

Reber, Arthur S. 1995. Dictionary of Psychology. London, Penguin Books. Walker, Melissa. 1991. Down from Mountaintop: Black Women Novels in the Wake of the Civil Rights Movement 1966-1989. New haven, Yale University Press. 